\title{
ANALYZING THE GLOBAL PROBLEMS OF THE TWENTY-FIRST CENTURY. A REVIEW AND FORECAST BASED ON THE REPORT TO THE CLUB OF ROME 'COME ON!'
}

\author{
Anton L. Grinin \\ Lomonosov Moscow State University, Moscow \\ Leonid E. Grinin \\ HSE University, Moscow; \\ Institute of Oriental Studies, Russian Academy of Sciences, Moscow

\begin{abstract}
In the last third of the twentieth century, global problems came to the fore. Many of these problems remain relevant today and have become even more alarming. This is especially true with respect to the climate change. The twentyfirst century is called the 'century of globalization' since from the very beginning it turned a period of turbulent, violent and unexpected events. In most societies and in the World System in general, the extensive new political, economic, ideological and other processes have already manifested themselves. The world is on the eve of serious transformations since globalization makes change the priorities, forcing to reconsider approaches to many problems and their solutions. In this context, it is crucial to understand and evaluate the course of human development. The present article provides a brief overview and analysis of the report of the Club of Rome 'Come On!' The Club has long been known as one of the centers focusing on the research of global problems of the humankind and their reports give impetus to the discussion of developmental strategies of societies. The report has been written by the current presidents on the occasion of the Club's anniversary and it has undoubtedly become one of the key events in the work of the Club. In the report, the authors seek to show the threats that have emerged by the end of the second decade of the twenty-first century and the ways to solve problems common to all humankind. This article analyzes the main problems, postulates, forecasts and proposals of the report, and presents the authors' ideas concerning the most important points of global development and future processes. We also argue that the twenty-first century is characterized not only by the global problems inherited from the previous century, but also by its peculiar emerging global challenges that used to be of local or country-scale. In other words, globalization transforms local and regional problems into the global ones.
\end{abstract}

Keywords: the Club of Rome, 'Come On!', globalization, world development forecasts, global problems, Cybernetic Revolution, global warming, Africa, new technologies.

In the last third of the twentieth century, the world spoke loudly about global problems. The threats of nuclear war, climate change, environmental degradation, poverty, and

Journal of Globalization Studies, Vol. 12 No. 2, November 2021 181-195

DOI: $10.30884 / j o g s / 2021.02 .10$ 
malnutrition were considered especially alarming. Yet, there were many other global problems (for more details see Chumakov 1994, 2014; Mazour et al. 2003). Many of them have moved into the new century and became even more threatening. This especially refers to the climate change. Meanwhile, as we will show below, the twenty-first century has its own peculiar global problems that might have existed earlier albeit at the local or country level. In addition, it is important for the subject of our study to emphasize the fundamental idea: in the context of globalization, many local and regional problems evolve into the global ones.

The Club of Rome is one of the most active organizations that systematically attract attention to the global problems (Meadows et al. 1972; Mesarovic and Pestel 1975; Gabor et al. 1978; de Montbrial 1979; Pestel 1988; Van Dieren 1995; Wijkman and Rockström 2012; Bardi 2014).

The Club of Rome is an international public organization. It was founded by the Italian industrialist Aurelio Peccei and Alexander King (at that time the DirectorGeneral for Scientific Affairs at the OECD) on April 6-7, 1968. The Club brings together entrepreneurs, managers, politicians, high-ranking officials, trusted experts, cultural figures, scientists, etc. However, the attitude towards the activities of the Club of Rome is rather ambiguous.

The Club of Rome published a total of 60 reports. Among them twenty-two reports are related to environmental issues. Other nine reports are political and economic models, four reports are management models whose framework is supposed to help in solving of environmental problems. Two reports are devoted to the development of technology, eight - to the development of the Third world countries, nine - to education, labor market and human development. Several reports cannot be attributed to any of these groups (Peresleghin and Lukovnikova 2021).

In 2017, there was presented the report 'Come On!' (Wijkman, Weizsäcker 2018) which was written by the Club's current presidents Ernst von Weizsäcker and Anders Wijkman with contributions from other thirty-four members. 'Come On!' is the anniversary report of the organization, expressing the common position of its members, which, of course, should be considered as a key event in the history of the Club of Rome, and perhaps, it is one of the most important documents of our time (Malakhov 2018). In 2019 and 2021, the Club of Rome also published several reports.

\section{Global Issues within the Concept of the Report and in Reality}

In the 'Come On!' report, the Club of Rome, which can be generally considered as a liberal-minded organization, harshly criticizes capitalism, opposes financial speculation, and calls for an alternative economy, a 'new Enlightenment', a holistic worldview, and planetary civilization. The report relies on the concept of a 'full world', proposed by the American ecologist and economist in Environment Department of the World Bank Herman Daly (2015), in which he developed the principles of sustainable development (he is also one of contributors of the report).

The 'Come On!...' report continues the line of the famous 'Limits to Growth' (Meadows et al. 1972) ${ }^{2}$ as well as of the subsequent works whose major idea was 'to stay away from catastrophe' (Peccei 1981), primarily through limiting the population growth and resource consumption. This direction, perhaps, is at the same time the strength of the report 'Come On!' and its weakness (see below). However, according to the authors, alongside with the main problem of resource depletion, the time has come to revise the very philosophy of development. 
The report consists of three chapters (parts). The first chapter - 'C'mon! Don't Tell Me the Current Trends Are Sustainable!' - reflects the current absence of sustainable development trends and aims at demonstrating the depth of the current crisis and the trend towards its aggravation; the second one, entitled 'C'mon! Don't Stick to Outdated Philosophies!', is devoted to the criticism of the dominant outdated worldview and to the presentation of an alternative philosophy; the third chapter - 'Come On! Join Us on an Exciting Journey Towards a Sustainable World!' - is devoted to practical solutions. However, it is worth noting that despite the fact that such a division of the report is indicated by the authors, it is hardly always possible to define in the text what is just a description of the problem, as well as whether it is an analysis or a recommendation. Perhaps, this has occurred because it is a multi-contributor book so there are about forty contributors besides the two main authors.

The title of the report is also unusual. After all, the expression 'come on' has two meanings: 'do not try to fool me' and 'join us', and is more appropriate for an informal and young audience (Wijkman, Weizsäcker 2018: vi; see also comments, e.g., Marien 2018).

The first part is devoted to the analysis of the current situation. The world is in danger of a catastrophe. 'The crisis is not cyclical, but growing. And it is not limited to the nature around us. There are also a social crisis, a political and cultural crisis, a moral crisis, as well as a crisis of democracy, of ideologies and of the capitalist system' (Wijkman, Weizsäcker 2018: 2). The authors perceive that the world is on a threshold which is much spoken about and which is really close (for details see below). However, in our opinion, the authors do not fully comprehend the nature of this turning point.

The climate change and environmental problems. One of the main problems of our time, according to the authors, is the climate and environmental issues. Of course, the environmental problem has long been among the global ones. In the report, it is presented as the major challenge both in terms of its scale and attention it gets.

The climate change (warming) is marked out as the most dangerous problem. But the report also shows that environmental limits are perceived in almost every other area. Thus, the processes of depletion of stratospheric ozone, chemical pollution of water, air and soil have reached dangerous limits, in particular, the flows of nitrogen and phosphorus go to the biosphere and oceans, so there occurs acidification of the ocean, the consumption of fresh water is increasing and the global hydrological cycle is changing (Wijkman, Weizsäcker 2018: 15). We live during the Anthropocene, the geological era, when human activity becomes decisive for the planet. It is estimated that humans and farm animals together account for 97 per cent of all vertebrates by weight; all other vertebrates, from bats to elephants, account for only 3 per cent (Ibid.: 16). The problem of carbon emissions is also really severe (Ibid.: 32, 54, 70, etc.). The Paris Agreements decided to reduce emissions for 'holding the increase in the global average temperature to well below $2^{\circ} \mathrm{C}^{\prime}$ (UNFCCC 2015: 21). The authors sound the alarms that this will be not enough and propose more drastic measures. Another authors' concern is that synthetic biology creates viral and bacteriological organisms with novel and deadly characteristics that can spread around the world (Wijkman, Weizsäcker 2018: 25). ${ }^{3}$ According to the authors, the problem of large-scale reduction of biodiversity is really urgent. Also the soil erosion, drought, floods, invasions of certain species (Ibid.: 24-25) can significantly increase the dangers faced by the future generations. Another problem is the production of agriculture-based bio-fuels. According to the authors, this is actually permissible, but if one starts to use fertile soils for this purpose, as, for example, in the United 
States, or virgin forests in Indonesia (for the production of palm oil), the social and climatic consequences may considerably surpass financial benefits (Wijkman, Weizsäcker 2018: 26).

Even this brief description makes it clear what importance the authors attach to environmental issues. Moreover, almost all other considered problems are somehow associated with them. However, the authors often fail to notice deep contradictions in their approaches. For example, while supporting the elimination of poverty in the world (another global problem) and at the same time the environmental improvements and limited resource consumption, they ignore the question of how the poor countries may raise their living standards without increasing the environmental burden. After all, the successes achieved by China, India and other countries in reducing poverty in their countries were associated with large-scale environmental pollution and a sharp increase in the burden on it.

The problem of human impact on the environment. Another threat is the growing opportunities for direct regulation of natural and biological processes. The authors of the report acknowledge that although economic growth is compatible with technological progress, from the moment when human activity reached a certain level, there emerges a risk of irreversible abrupt changes in the environment. They emphasize the risk of using largescale technological impacts on the climate (geoengineering) to slow down or reverse the negative impact (Wijkman, Weizsäcker 2018: 23). The threat of introducing genetic engineering methods such as CRISPR-Cas9 is also mentioned (Ibid.: 6, 27). At present, the problem of increasing capabilities to manipulate human body can also be considered as global. We have no opportunity to dwell on this in the present study, but we refer the reader to our works on this topic (Grinin L., Grinin A. 2015, 2016).

In our opinion, the problem of modifying the environment is undoubtedly very important. However, this process requires a thorough comprehension and regulation. For example, the issue of genetic modification of plants must be considered from different aspects, both from the perspective of health risks and from the perspective of addressing the problem of malnutrition in undeveloped countries.

The problem of overpopulation. Another global problem raised by the Club of Rome is the threat of overpopulation (although, in our opinion, its relevance has already considerably decreased). As we wrote above, along with environmental problems, overpopulation is pivotal for the Club and has been discussed since its foundation. The authors of the report regret that the solution to the problem of overpopulation is not carried out systematically, and in their opinion, the measures are ineffective, although in many developing countries the birth rate is on the verge of simple population reproduction and in some countries even below this level. According to the directors of the Club, in 2012 the lower limit of the biocapacity of population was 7 billion people, while the situation would have been much better if the world population had stabilized at the border of less than 3.5 billion people 50 years ago (Wijkman, Weizsäcker 2018: 27). According to the forecasts, the stabilization of the population number will not occur earlier than the second half of the twenty-first century after exceeding ten billion people. The authors acknowledge that, of course, this is an extremely delicate issue in the political aspect, but they continue to insist on the necessity to reduce the birth rate as much as possible. At the same time, they note that it is incorrect to consider the population growth to be the only reason for the increase in the burden on the planet. Recently, the 'great acceleration' period has clearly shown that by itself it does not explain the massive increase in human impact on the environment. Thus, the economic indicators increased by 40 times, fish 
catch - by 35 times, the use of fossils - by 16 times, and water consumption - by nine times. According to the directors of the Club, the problem of climate and environmental pressure would be much less acute if the population did not exceed 9 billion people (Wijkman, Weizsäcker 2018: 30). The report provides two population projections: 'high education' scenario ending up with 8.5 billion people by 2050 and 'Low Education' scenario ending up with 10 billion people by 2050 (Ibid.: 29). In their projections, the authors rely on the research on the impact of female education level on population growth. According to such studies, better educated women tend to have fewer children, better overall health, and higher infant survival rates. Thus, the goal of slowing down the population growth depends to a large extent on the further progress in education (Samir, Lutz 2017).

In our opinion, the authors treat the problem of population growth and relative overpopulation not entirely correctly. Thus, one may get an impression that they look more into the past regarding this problem and fail to get away from the ideas of 50 years ago. In the future, the problem of rapid population growth and overpopulation will be very noticeable not in the whole world, but mainly only on one (African) continent.

This is not to say that the Club did not pay attention to African problems. In 1987, 'L'Afrique face à ses priorités (Africa facing its priorities)' (Schneider 1987) was published in the Club of Rome's 'Information Series'. Soon, in 1988, the report 'The Barefoot Revolution' was written by Bertrand Schneider (1988). It continued the topic of the Third World countries, focusing on many problems, especially in agriculture. In 1989, another report 'Africa Beyond Famine' (Lemma and Malaska 1989) was introduced which became a continuation of works on Africa. Then it was a long break, and only in 2021, a new report was released, entitled 'Towards New Narratives of Hope for Fostering Transformative African Futures' (Preiser et al. 2021), which was dedicated to extraordinary planetary cooperation. However, in all these publications as well as in other reports, there is not enough attention paid to the problems of population growth. Meanwhile, in Africa, the population may grow from 1.2 billion to 3 billion or more by 2100 . Perhaps, it is better to focus more on African demographics, rather than on the global population growth.

Unfortunately, it is depopulation that is becoming a global problem, since by 2050 the population of dozens of countries will greatly reduce and even more so by 2100 . Thus, according to one of the main scenarios for the period from 2017 to 2100 , twenty-three countries, including Japan, Thailand and Spain, will face a significant reduction in population, by more than 50 per cent, while the population of China will decline by 48 per cent (Vollset et al. 2020).

Economic problems and growing inequality. As we have already mentioned, the report pays considerable attention to economic problems. The authors note that big capital has become too arrogant (Wijkman, Weizsäcker 2018: 64); so the problem of capital outflow from large corporations in order to avoid taxation is exacerbating, and that millions of jobs are threatened with extinction (Ibid.: 6, 49). Of course, this problem is not new since technological progress typically reduces jobs (and at the same time creates new ones), but now it is becoming global. It is worth noting that the problem of disappearing jobs is considered very superficially, since many analysts show that the substitution of jobs will hardly proceed simultaneously and in the same way in all professions (see, e.g., Frey, Osborne 2017); in addition, the situation will change due to the population aging (Grinin L., Grinin A. 2015).

The problem of income inequality and quality of life is especially emphasized. The authors cite popular facts that 800 million people on Earth still suffer from chronic malnu- 
trition, while about 2 billion are overweight $;^{4}$ at the same time, the middle class in developed countries has been shrinking for 20 years, and the rich make up 1 per cent and eight richest people have more wealth than all the poor people combined (Wijkman, Weizsäcker 2018: 32). ${ }^{5}$ The Club of Rome considers this as the signs of the crisis of capitalism. The authors argue that the degradation of capitalism began already in the 1980s, when financial speculation became the main source of profit, which led to the global financial crisis of 2008-2009. However, the bankers not only maintained their positions but also became 'too big to fail and too big to jail' (Ibid.: 8). The authors also point to aggravating problems in the financial sector, especially related to financial bubbles. The current system may recurrently lead to currency crashes, sovereign debt crises and systemic crashes, with an average of more than ten countries being in crisis annually. ${ }^{6}$ The authors of the report also mention the problem of inadequate economic indicators, in particular, of the GDP.

Speaking about the destructive role of capitalism, we think one should keep in mind that the system of classical, that is, industrial, capitalism (of the twentieth century), which for a long time determined scientific and technological progress, has found itself on the periphery of modern economy in developed countries. The matter is that it has entered into an unequal struggle against global financial and information imperialism. In other words, it is impossible to solve global problems while ignoring the fact that it is financial and digital globalization (that is, the cooperation of the largest financial, media and information corporations) that is largely the source of these problems.

The problem of technological progress and other challenges. The authors of the report express concern about the theory of exponential growth (known primarily due to Ray Kurzweil and Peter Diamandis), especially because of the so-called 'rebound effect', according to which increased efficiency leads to increased consumption and, as a result, to increased damage to the environment (Wijkman, Weizsäcker 2018: 48).

The authors of the report, however, believe that 'Moore's law will not work forever and its dynamics will fundamentally change around 2020 or 2025, and the miniaturization of transistors seems close to its end' (Ibid.: 48). At the moment, many experts agree with this (see, e.g., Peercy 2000). Although there are other opinions, for example, that transistors will stop decreasing, however Moore's law may persist (Anthony 2016). We believe that miniaturization and microminiaturization will continue, since it is one of the key characteristics of the new technological revolution (Grinin L., Grinin A. 2015). However, the transition to a new trajectory of microminiaturization will not be a linear process; it is possible only on the basis of new major innovations.

The authors of the report point out an interesting problem of digitalization and techno-utopianism, which they show in the framework of development of artificial intelligence and generational conflicts. Thus, according to the authors, modern young people consider themselves as 'digital natives' and look down on 'digital immigrants', that is, older people who grew up with books, pens and paper. ${ }^{7}$ The report draws attention to the shadow side of digital economy. For example, services like Uber and their users do not share common costs (for urban infrastructure used by drivers, etc.) - and in their current form do not meet sustainability criteria.

It is noteworthy that when speaking about young people and the shadow side of the digital economy, the authors of the report do not mention the impact of computer games. Meanwhile, the situation has loomed large and become a real global problem. Despite the fact that this problem is often not discussed, in 2019 the World Health Organization was forced to officially include 'play disorder' in the list of the international classification of diseases (Kamenetz 2019). Today the inference of games and social networks for teen- 
agers is evident. Even the US Senate has recently discussed this issue regarding Facebook CEO Zuckenberg. However, his new plans with now a new company ('Meta') could endanger teenagers' mental health even more than the previous ones.

It is also worth noting that when speaking about the development of technologies, the authors practically do not mention artificial intelligence (AI), it is mentioned only in the context of general problems. Today, a number of researchers (see, e.g., Plebe, Perconti 2020) including the head of artificial intelligence at Facebook (Knight 2019) note a slowdown in the development of AI. However, it is obvious that this direction will be one of the key factors in the development of technology, since it will dramatically increase the self-regulating technology, which, in our opinion, will become the main trend of the new technological revolution (Grinin et al. 2020). The artificial intelligence will become an integral part of many products and services and it will significantly increase productivity, but at the same time will also be a source of a number of problems in terms of rising unemployment and increasing inequality (Makridakis 2017). However, the associated attack on human rights appears especially dangerous. This global problem of the twenty-first century seems threatening.

Among other problems of our time, the report mentions military conflicts, including in the Middle East, some African countries, Afghanistan and Myanmar. Another problem is the almost forgotten threat of nuclear weapons (Wijkman, Weizsäcker 2018: 27).

In general, despite the fact that the report touches a wide range of problems, in our opinion, the overall picture is not clear enough, partly due to its excessive alarmism.

\section{What the Authors of the Report have Missed}

In this section, we will consider the report in more detail and analyse some of its weak points in relation to global problems.

The global problem of climate change. As we have already pointed out, this issue occupies a disproportionately large volume in the report, given that the purpose of the work is to address all major global issues. Similar to other reports of the Club of Rome, the 'Come On!' report completely ignores alternative views on the causes of global warming and alternative scenarios related to the assessment of the available natural resources.

The development of technologies already contributes in a way to the solution of environmental problems and will certainly continue to do it in the future. The refining technologies help reduce $\mathrm{CO}_{2}$ emissions, and may even allow carbon dioxide to be used for recycling, for example, into chemical feedstock for the production of plastics and fuels (Blundell 2020). Biotechnology and nanotechnology (via self-regulated systems of purification and processing, the creation of new artificial biomaterials, etc.) may help to solve the problems of pollution of cities, water bodies, as well as of the waste disposal.

Is resource scarcity a global problem? As we have already mentioned, the concept of the Club of Rome is based on the World 3 model stating the limited resources for development. Fifty years later, the authors of the report 'Come On!' continue to rely on it. Thus, for example, they write, 'We now live in a world full of human infrastructure. The human footprint has grown so large that, in many cases, limits on the availability of natural resources now constrain real progress more than limits to consumer goods' (Wijkman, Weizsäcker 2018: 179). Meanwhile, the model presented in the report 'The Limits to Growth' (Meadows et al. 1972) has not confirmed its relevance. The foreseen catastrophe of lack of resources has not happened. Thus, for example, despite the population growth by two and a half times after 1961 (World Bank 2020a), the food production index has almost quadrupled (Ibid.). According to the model and in the fore- 
casts of the report 'Limits to Growth' the lack of resources in the 2000s should have led to a sharp decline in the amount of food per capita. In reality, between 2000 and 2016, the malnutrition decreased by more than 30 per cent (World Bank 2020b).

Why is the model so imprecise? In our opinion, similar to the 'Come On!' report, it does not take into account the impact of technological progress. The late twentieth early twenty-first century coincides with the final phase of a new industrial revolution (which we call the Cybernetic). The final phase will begin in the 2030s - 2040s and will last until the 2060s - 2070s. During this period, there will happen a transition to production and services based on the 'smart' and self-regulating systems. This phase, according to our forecasts, will also overlap with the sixth Kondratieff wave (which we date to the 2020-2060s). The Cybernetic revolution will be characterized by a breakthrough in medicine that can unite many other technologies. Together they will form a complex system of self-regulating production. We designate this complex as MANBRIC-technologies, according to the first letters of the technologies included in it (medicine, additive, nano-, biotechnology, robotics, information and cognitive technologies). According to our forecasts, the final phase will not only significantly increase the expected duration and quality of human life, but will also lead to the emergence of an opportunity to change and modify the very biology of human body (Grinin L., Grinin A. 2015; Grinin A., Grinin L. 2015; Grinin et al. 2017; 2020; 2021a).

So, at present the humankind is rather successfully coping with the problem of resources. In the medium term, the discovery of new energy sources or a sharp reduction in the cost of existing ones are quite possible.

It is characteristic that the Club of Rome focuses mainly on natural resources, while the role of the human factor in production and economy is generally increasing. Meanwhile, the report does not consider the quantity and quality of the working population from the point of view of its limited availability, on the contrary, it expresses ideas about its excessiveness and forthcoming huge reduction in employment. The report states:

According to the International Labour Organization (ILO), the world would need roughly one billion additional jobs to overcome global unemployment. This is actually Sustainable Development Goal (SDG). It would mean that developing countries need to create more than 50 million new jobs every year. At the same time, even in the poorest countries, the capacity of agriculture to absorb additional labour is rapidly diminishing (Wijkman, Weizsäcker 2018: 110).

In our opinion, in developed and middle-developed countries, as well as in many developing countries (except for Africa, see above), there is a real or potential shortage of labor resources. However, we believe that while the future technological wave will bring major changes in the structure of employment with inevitable costs and negative consequences, it will also be able to alleviate the problems of limited labor force (associated with a decrease in youth and with population aging). This will happen not so much due to demographic growth, but primarily due to an increasing level and quality of life. First of all, thanks to breakthroughs in medicine that will contribute to the increase of working age and quality of biological life. The artificial intelligence supports the expansion of opportunities for remote work which may reduce unemployment, making the labor market largely global. Nevertheless, the problem of surplus labor is and will remain urgent in the regions with a rapidly growing population, where the so-called 'youth bulges' will increase. These are primarily countries in sub-Saharan Africa. ${ }^{8}$ 
Technologies can provide an impetus for a further increase of nutritional resources. It is interesting that the authors of the report often offer the right ideas but do not develop them into the required solutions. Thus, on the one hand, they constantly speak about the limited resources and impossible expansion of the economy to reduce their deficit. On the other hand, they give good examples of farms for growing fish, algae, shellfish and other types of marine resources. Thus, they overlook the opportunity for a global solution to the food problem by means of the cultivation of marine and river animals and plants. Given the vast undeveloped aquatic regions and new agricultural technologies, the transition from harvest to artificial farming could help to cope with the problem of growing population. In other words, a transition from an appropriating economy (catching wild species) to a producing one (growing) is necessary in the marine and river economy, similar to what once occurred in agriculture.

The technological development is likely to solve many political problems, such as, for example, the global contradictions between the aging North and the young South ${ }^{9}$ the trend towards gerontocracy (due to the growing share of the elderly population in society) and a possible crisis of democracy; excessive influence of global capital on world politics; negative impact of the emerging electronic state on the human rights and freedoms. We understand electronic state is a state with a significantly reduced number of state supervisory bodies, mainly based on SSS technology. ${ }^{10}$

The improvement of self-governing social systems and limiting the opportunities of the electronic state, as well as using cryptocurrencies to limit the influence of financial capital may become possible solutions (on some opportunities see Grinin 2019; Grinin L., Grinin A. 2015; 2016; Grinin et al. 2020; 2021a).

As we pointed above, the issue of climate change and resource depletion driven by industrial production and increased consumption, in fact, contradicts one of the main ideas of the report concerning the fight against poverty. Today it seems highly improbable that a state, especially with a large or growing population, can move to a highly developed stage without massive industrial production and increasing pressure on natural resources. At the same time, the costs of preserving the environment are unbearable for such countries. The solution of this issue by international communities and organizations is still ineffective. On the contrary, in the process of globalization, the less developed countries are often used to withdraw the polluting industries from developed countries, which, in turn, increasingly monopolize the financial sector and the service market.

An error in the demographic forecast. In our opinion, the demographic trends are among the main neglected points of the report to the Club of Rome 'Come On!' In particular, it ignores the factor of population aging. According to the UN data (WIPO 2020), a sharp increase in the elderly population numbers is expected in the twenty-first century. The growth in the total number of people of retirement age will be especially rapid in the next two decades: during this historically short period of time it will practically double and, in general, will noticeably exceed a billion people. However, a particularly rapid acceleration will be observed in the global number of population over 80 . Compared to 1950, their number will increase by almost 50 times by 2075 .

At the same time, the greatest difficulties in the next 20-30 years will await the countries of the First world, where the rapidly growing number of people of retirement age will be accompanied by an ever-accelerating reduction in the number of people of active working age, and in 20 years the number of the former is likely to exceed the number of the latter (Grinin 2018; Grinin, Korotayev 2020). 
The authors of the report do not take into account that the population aging will be the most important factor determining the development in the twenty-first century. We believe that at the first stage, that is, in the coming decades, global aging may become a driver of a technological breakthrough. This may happen for several fundamental reasons. First, an aging population not only in developed but also in developing countries will lead to a sharp increase and development of medical services. Secondly, the development of peripheral and developed countries will be leveled. Thirdly, the population aging will increase the labor shortage in a number of countries, including Russia, which will cause additional demand for technologies replacing human labor, especially the low-skilled labor. At the same time, the population growth along with technological progress will lead to socio-political destabilization in the World-System, which may begin in the next 15-20 years (Grinin L., Grinin A. 2019; Grinin, Grinin, Korotayev 2021b). This corresponds to the cycle of the Cybernetic revolution, whose modernization phase should cause social and economic upheavals, after which a new wave of technological revolution will start (for more details see Grinin L., Grinin A. 2015; 2016; Grinin et al. 2017; 2020, 2021a).

Also, according to the theory of Kondratieff waves, the next decade is likely to become a period of the downward phase of the fifth Kondratieff wave, that is, generally depressive, which always increases tension (Grinin et al. 2017).

Population aging will affect not only technological development but also other spheres, including the economic development. We disagree with the assertion of the authors of the report that uncontrolled consumption is a phenomenon that will only intensify if the course of development is not changed. At present, the consumption largely depends on the young generation of developed countries where the demographic situation is changing dramatically. In the middle of the twenty-first century, when the elderly population starts to dominate in these countries, the structure of economic demand will considerably change. The elderly are likely to consume less innovation, but spend more on health services, and also the population's savings may increase. Many sectors of the economy will have to significantly transform (see Grinin L., Grinin A. 2019; Grinin, Grinin, Korotayev 2020).

The global problems of aging in many countries, the growth of the population in Africa and the decline in fertility require a comprehensive solution which may be contributed by the supposed breakthrough in medicine (due to its impact on life expectancy and reproductive capabilities, genetic engineering, treatment of hereditary diseases, improvement of biological quality life, etc.).

\section{Conclusion}

In its report, the Club of Rome often emphasizes that it describes global problems, like global environmental and climate problems, global economy, global development, etc. But is the report of really equal value for all countries? Unfortunately, one can easily notice the authors' Westcentrism. ${ }^{11}$ The Club of Rome presidents are so accustomed to living and thinking within the Western paradigm that they do not even specify who their recommendations are intended for. But it is clear from the report itself - for the Western reader. However, even today the aging West with its non-growing economy starts to give way to developing and growing Asia. The trend will continue, and in a few decades, along with the growing share of the world's population, the development center will gradually move to the African continent. ${ }^{12}$ However, there is no analysis of how the cultural and political characteristics of Africa will transform with the growing economic importance of 
this continent; in fact, this question is not even raised. In other words, the report can be viewed as a very indicative survey of modern Western political thinking, which is in search of solutions to growing problems, but cannot abandon the West-centric view.

We want to conclude with the idea that the world is currently in search of answers to critical questions: whether modern global economy is destined to complete resource depletion of both production and climatic resources? Are we at the threshold of no further development? And is there a necessity to reject the aspiration for economic growth? Is there any urgent need to reduce consumption and change the whole production system connected with market, pursuit of gain, and instead create a system of regulation, social redistribution and self-limitation on a global scale? In other words, whether the time has come to change modern capitalism for something like state capitalism or socialism of a new type, since modern capitalism (= current industrialism) has exhausted its opportunities for growth and expansion and poses threats to the climate and future development.

We have no definite answers to them. On the one hand, the tasks of climate preservation are imperative, but on the other we still believe that although today we are on the eve of considerable transformations which will probably lead to increasing economic and technological regulation, the opportunities and reserves for normal (and accelerated) economic growth will preserve for at least the nearest half century or even to the end of the century (see Grinin L., Grinin A. 2021a, 2021b; see also Akaev et al. 2019). ${ }^{13}$

In addition, when choosing a strategy for reducing greenhouse gas emissions, we must base on the recognized world documents, especially the Paris Agreement, which says that a strategy for reducing greenhouse gas emissions should combine with a strategy for sustainable development. Thus, the standard of living should not decrease but rise, poverty should be eradicated, and food production should not decline (see UNFCCC 2015). And the interests of developing countries should be especially taken into account.

There are a number of factors, including the developing Third world, a new technological wave, and some others, which will provide favorable environment conditions for economic growth and support pursuit of gain as a necessary and important impetus for societal development (including innovations). Still the directions, sources and centers of economic growth will certainly change. And the society's objective is to find the ways to canalize development towards a generally advantageous direction and to find an optimal combination of private initiative with social program, and of the increasing consumption as a source of economic development with optimized consumption.

\section{Funding}

The study has been supported by the Russian Scientific Foundation (project № 20-6146004).

\section{NOTES}

${ }^{1}$ Conspiracy theorists consider it as the harbinger of future development, others regard the Club as a kind of 'shadow institution' that draws up the plan for the development of civilization (see, e.g., Onuf 1983) and is a 'think tank' guarding interests of the 'global power brokers': the Bilderberg Group, the Committee of 300 and others (see, e.g., Khmelevsky 2014).

${ }^{2}$ So far this is the most famous work of the Club. The report was based on the World 3 computer model, which was led by Jay Forrester's assistant Donella Meadows. The computer model examined the behavior of the global system over a timespan of two hundred years - from 1900 to 2100 - and was based on five variables: population, food production, industrialization, pollution, and consumption of non-renewable natural resources.

${ }^{3}$ The coronavirus pandemic, by the way, has shown that these are far-fetched fears. 
${ }^{4}$ This problem emerged already in the last century, but today, in the twenty-first century, it expands to the global level.

${ }^{5}$ The situation is similar with this problem. More precisely, the polarization of population in terms of income is observed throughout history, but today it is turning into a global one, since the financial capital has globalized.

${ }^{6}$ The described problem is adjacent to the one indicated in Endnote 4, while the transformation of financial capital into a global one makes global problems from all its shortcomings.

${ }^{7}$ The problem of the generation gap became very acute already in the past, if not in the nineteenth century. However, due to globalization of the media and Internet space, it is also moving to the global level.

${ }^{8}$ Thus, the problem of overpopulation will narrow from a global to a continental scale, although its global impact will go far beyond the borders of Africa. At the same time, the problem of labor shortages will grow from a country to a global level, although one may hope that the new technological wave will significantly mitigate it.

${ }^{9}$ This may become a truly global problem.

${ }^{10}$ Socio-technical self-regulating systems (SSS) perform social and administrative functions (that is, control, verification, distribution, security, rating and other functions) using a set of technologies in the absence or little participation of officials and specialists (Grinin et al. 2020, 2021a).

${ }^{11}$ The Club of Rome has released only a few reports concerning the third world countries: 'Third World: Three Quarters of the World' (Guernier 1980). The report describes reforms in agriculture in developing countries, its decentralization and the need to respect nature in the third world. In the same year, the report 'Dialogue on Wealth and Welfare' (Giarini 1980). The third - in 1980 - was the report 'Towards More Effective Societies' (Hawrylyshyn 1980). Meanwhile, there are many complains on the lack of synthetic views of the world problems with a full-fledged analysis of situations in different parts of developing countries (e.g. Olatunji and Bature 2019).

${ }^{12}$ Along with the problem of the rapidly growing population of sub-Saharan Africa, the accelerated economic growth in African countries will constitute a single problem that will go far beyond the boundaries of the African continent, and in terms of status it will be between continental and global scale.

${ }^{13}$ Now the authors are working within the group of Russian scientists on the report to Club of Rome titled 'Beyond of Limits' in which we will hope to give answer on some these questions.

\section{REFERENCES}

Akaev, A., Rudskoi, A., Sarygulov, A., and Sokolov, V. 2019. A New Era of Machinery: Will the Accumulation of Capital Grow and Labor Intensity Decrease? Social Evolution and History 18 (1): 67-93. DOI: 10.30884/seh/2019.01.04.

Anthony, S. 2016. Transistors will Stop Shrinking in 2021, but Moore's Law will Live on. Ars Technica, July 25. URL: https://arstechnica.com/gadgets/2016/07/itrs-roadmap2021-moores-law/.

Bardi, U. 2014. Extracted: How the Quest for Mineral Wealth is Plundering the Planet. White River Junction: Chelsea Green Publishing.

Blundell, S. 2020. New Technology Could Turn CO2 Waste Emissions into Useful Materials. 2020 Open Access Government, July 25. URL: https://www.openaccessgovernment.org/ technology-to-turn-co2-waste-emissions-into-useful-material/915.

Budyko, M. I. 2002. Global Warming. In Menzhulin, G. V. (ed.), Climate Change and Their Consequences (pp. 7-12). Saint Petersburg: Nauka. Original in Russian (Будыко М. И. Глобальное потепление // Изменения климата и их последствия / отв. ред. Г. В. Менжулин. СПб.: Наука. С. 7-12).

Chen Xueming. 2017. Marxism and the Construction of an Ecological Civilization. In Lihuan Wu and Baixiang Liu (eds.), The Ecological Crisis and the Logic of Capital (pp. 427438). URL: https://doi.org/10.1163/9789004356009_021. 
Chumakov, A. N. 1994. Philosophy of Global Problems. Moscow: Znanie. Original in Russian (Чумаков А. Н. Философия глобальных проблем. М.: Знание).

Chumakov, A. N. 2014. Globalization. The Contours of the Integral World. Moscow: Prospekt. Original in Russian (Чумаков А. Н. Глобализация. Контуры целостного мира. М.: Проспект).

Daly, H. E. 2015. Economics for a Full World. Great Transition Initiative. URL: https:// greattransition.org/publication/economics-for-a-full-world.

Frey, C. B., Osborne M. A. 2017. The Future of Employment: How Susceptible Are Jobs to Computerisation? Technological Forecasting and Social Change 114: 254-80. URL: https:// doi.org/10.1016/j.techfore.2016.08.019.

Gabor, D., and Colombo, U. et al. 1978. Beyond the Age of Waste. Oxford, etc.: Pergamon Press.

Giarinin, O. 1980. Dialogue on Wealth and Welfare: An Alternative View of World Capital Formation, a Report to the Club of Rome. Oxford, etc.: Pergamon Press.

Grinin, A., Grinin L. 2015. The Cybernetic Revolution and Historical Process. Social Evolution and History 14 (1): 125-184.

Grinin L. 2018. Seven Weaknesses of America and Donald Trump. Vek globalizatsii 2 (26): 6-31. Original in Russian (Гринин Л. Е. Семь слабостей Америки и Дональд Трамп. Век глобализации. № 2 (26). С. 6-31).

Grinin L., Grinin A. 2015. From Choppers to Nanorobots. The World is on the way to the Era of Self-Governing Systems. Volgograd: Teacher. Original in Russian (Гринин Л. Е., Гринин А. Л. От рубил до нанороботов. Мир на пути к эпохе самоуправляемых систем. Волгоград: Учитель).

Grinin L., Grinin A. 2016. Coming Technological Revolution and Global Risks. Vek globalizatsii 4 (20): 40-58 Original in Russian (Гринин Л. Е., Гринин А. Л. Грядущая технологическая революция и глобальные риски. Век глобализащии. № 4 (20). С. 40-58).

Grinin L., Grinin A. 2019. Looking Ahead: Forecasts for the $21^{\text {st }}$ Century. Vek globalizatsii 3: 3-24. Original in Russian (Гринин Л. Е. Взгляд в будущее: прогнозы на XXI столетие. Век глобализаичи. № 3. С. 3-24).

Grinin L., Grinin A. 2021a. Reflections on the Economic Growth and Future. Part 1. Growth and the 'Decline of the West'. Filosofia $i$ obshchestvo 3: 5-34. Original in Russian (Гринин Л. Е., Гринин А. Л. Размышления об экономическом росте и будущем. Статья первая. Рост ВВП и «закат Запада». Философия и общество. № 3. С. 5-34).

Grinin L., Grinin A. 2021b. Reflections on the Economic Growth and Future. Part 2. Global Issues and the Economic Growth. Filosofia i obshchestvo 4. Original in Russian (Гринин Л. Е., Гринин А. Л. Размышления об экономическом росте и будущем. Статья вторая. Глобальные проблемы и экономический рост. Философия и общество. № 4).

Grinin L., Grinin A., Korotayev A. 2017. Forthcoming Kondratieff Wave, Cybernetic Revolution, and Global Ageing. Technological Forecasting and Social Change 115: 52-68. DOI: $10.1016 /$ j.techfore.2016.09.017.

Grinin L., Grinin A., Korotayev A. 2020. A Quantitative Analysis of Worldwide Long-Term Technology Growth: From 40,000 BCE to the Early $22^{\text {nd }}$ Century. Technological Forecasting and Social Change, 155. DOI: 10.1016/j.techfore.2020.119955.

Grinin L., Grinin A., Korotayev A. 2021a. COVID-19 Pandemic as a Trigger for the Acceleration of the Cybernetic Revolution, Transition from E-Government to E-State, and Change in Social Relations. Technological Forecasting \& Social Change. DOI: https://doi.org/10.1016/j.techfore.2021.121348.

Grinin L., Grinin A., Korotayev A. 2021b. Global Trends and Forecasts of the 21st Century. World Futures 77 (5): 335-370, DOI: 10.1080/02604027.2021.1949939. 
Grinin, L., and Korotayev, A. 2020. Seven Weaknesses of the U.S., Donald Trump, and the Future of American Hegemony. World Futures. https://doi.org/10.1080/02604027.2020. 1801309.

Grundmann R. 1991. The Ecological Challenge to Marxism. New Left Review, 19: 103-120.

Guernier, M. 1980. Tiers-Monde: Trois Quarts du Monde. Paris: Dunod.

Hawrylyshyn, B. 1980. Towards More Effective Societies: Road Maps to the Future. Oxford: Pergamon Press.

Kamenetz A. 2019. Is 'Gaming Disorder' an Illness? WHO Says Yes, Adding it to its List of Diseases. NPR, May 28. URL: https:// www.npr.org/2019/05/28/727585904/is-gamingdisorder-an-illness-the-who-says-yes-adding-it-to-its-list-of-diseases.

Keen S. 2020. Nobel Prize-Winning Economics of Climate Change is Misleading and Dangerous - Here's Why. The Conversation, September 9. URL: https://theconversation.com/ nobel-prize-winning-economics-of-climate-change-is-misleading-and-dangerous-heres-why145567.

Knight W. 2019. Facebook's Head of AI Says the Field Will Soon 'Hit the Wall'. Wired, April 12. URL: https://www.wired.com/story/facebooksai-says-field-hit-wall/.

Khmelevsky S. 2014. Threats and Challenges of Modern Russia through the Prism of the Prophecies of the 'Club of Rome'. Sotsialno-Politicheskie Nauki 1: 6-15. Original in Russian (Хмелевский С. Угрозы и вызовы современной России сквозь призму пророчеств «Римского клуба». Социально-политические науки. Вып. 1. С. 6-15).

Lemma, A. and Malaska, P. 1989. Africa Beyond Famine: A Report to the Club of Rome. Co-operation for Development Series, 6. London etc.: Tycooly Publishing.

Makridakis S. 2017. The Forthcoming Artificial Intelligence (AI) Revolution: Its Impact on Society and Firms. Futures 90: 46-60. DOI: 10.1016/j.futures.2017.03.006.

Malakhov A. 2018. 'Come on!' - the Anniversary Report of the Club of Rome. URL: https://malakhov.link/come-on-report. Original in Russian (Малахов A. 'Come on!' юбилейный доклад Римского клуба).

Marien M. 2018. Book Review of Come On!: A Report to the Club of Rome: New Frontiers. Cadmus, 3 (14): 1-12.

Mazour, I. I., Chumakov, A. N., and Gay, W. C. (eds.) 2003. Global Studies Encyclopedia. Moscow: Dialog, Raduga Publishers.

Meadows, D. H., Meadows, D. L., Randers, J., and Behrens, W. W. III. 1972. The Limits to Growth. New American Library Universe Books.

Menzhulin, G. V. 1992. The Impact of Expected Climate Changes on Crop Yields: Estimates for Europe, the USSR, and North America Based on Paleoanalogue Scenarios. Boulder, CO: Westview Press.

Menzhulin G. V. 1997. Global Warming, Carbon Dioxide Increase and the Prospects of Crop Potential. Journal of Agricultural Meteorology 52 (5): 377-407.

Mesarovic, M., and Pestel, E. 1975. Mankind at the Turning Point. New York: E. P. Dutton Hutchinson.

Montbrial, Th., de 1979. Energy: The Countdown. Oxford: Pergamon Press.

Murphy J. 2020. Wikipedia Censors List of Scientists Who don't Agree with Global-Warming 'Consensus'. The New American. March 10. URL: https://thenewamerican.com/wikipediacensors-list-of-scientists-who-don-t-agree-with-global-warming-....

Nordhaus W. 2018. Projections and Uncertainties about Climate Change in an Era of Minimal Climate Policies. American Economic Journal: Economic Policy, 10 (3): 333-60. DOI: $10.1257 /$ pol.20170046. 
Olatunji, F. O., Bature, A. I. 2019. The Inadequacy of Post-Development Theory to the Discourse of Development and Social Order in the Global South. Social Evolution \& History 18 (2): 229-243. DOI: $10.30884 / \mathrm{seh} / 2019.02 .12$.

Onuf, N. 1983. Reports to the Club of Rome. World Politics, 36 (1): 121-46. URL: https:// doi.org/10.2307/2010178.

Peccei, A. 1981. One Hundred Pages for the Future. Amsterdam: Pergamon.

Peercy, P. S. Ps. 2000. The Drive to Miniaturization. Nature, 406 (6799): 1023-1026. URL: https://doi.org/10.1038/35023223.

Peresleghin, S., and Lukovnikova, N. 2021. The Limits that Choose Us. The Club of Rome Papers: An Experience of Schematization. Ekonomicheskiye strategii 4: 76-91. Original in Russian (Переслегин С., Луковникова Н. Пределы, которые нас выбирают. Доклады Римского клуба: опыт схематизации. Экономические стратегии. № 4. С. 76-91)

Pestel, E. 1988. Beyond the Limit to Growth. New York: Universe Books.

Plebe, A., Pietro, P. 2020. Plurality: The End of Singularity? In. Korotayev, A. V., LePoire, D. J. (eds.), The 21st Century Singularity and Global Futures (pp. 163-184). Cham: Springer International Publishing, DOI:10.1007/978-3-030-33730-8_8.

Preiser, R., Swilling, M., Nnoli-Edozien, N., and Ramphele, M. 2021. Towards New Narratives of Hope for Fostering Transformative African Futures. Club of Rome. URL: https://www.clubofrome.org/wp-content/uploads/2021/01/COR-ENCI_NewNarratives_Dec 2020_A4-v1-1.pdf.

Samir, K. C., Lutz, W. 2017. The Human Core of the Shared Socioeconomic Pathways: Population Scenarios by Age, Sex and Level of Education for All Countries to 2100. Global Environmental Change. 42: 181-192.

Schiller, G. 1980. Manipulators of Consciousness. Moscow: Mysl. Original in Russian (Шиллер Г. Манипуляторы сознанием. М.: Мысль).

Schneider, B. 1987. L'Afrique face à ses priorités. Paris: Economica.

Schneider, B. 1988. Barefoot Revolution: A Report to the Club of Rome. Intermediate Technology Publications.

UNFCCC - United Nations Framework Convention on Climate Change. 2015. Paris agreement. Report of the Conference of the Parties to the United Nations Framework Convention on Climate Change (21st Session, 2015: Paris). URL: https://unfccc.int/ files/home/application/pdf/paris_agreement.pdf.

Van Dieren, W. (ed.) 1995. Taking Nature into Account: Toward a Sustainable National Income. New York: Springer.

Vollset, S. E., Goren E., Chun-Wei Y. et al. 2020. Fertility, Mortality, Migration, and Population Scenarios for 195 Countries and Territories from 2017 to 2100: A Forecasting Analysis for the Global Burden of Disease Study. The Lancet, July. DOI: 10.1016/ S0140-6736(20)30677-2.

Wijkman, A., and Rockström, J. 2012. Bankrupting Nature: Denying Our Planetary Boundaries. New York: Routledge.

Wijkman, A., and Weizsäcker, E. von. 2018. Come On! Capitalism, Short-termism, Population and the Destruction of the Planet. A Report to the Club of Rome. New York: Springer.

WIPO. Intellectual Property Statistics Data Center. 2020. September 10. URL: https://www3. wipo.int/ipstats/.

World Bank. 2020a. Food Production Index (2004-2006 = 100). September 28. URL: https:// data.worldbank.org/indicator/AG.PRD.FOOD.XD.

World Bank. 2020b. Prevalence of Undernourishment (\% of Population). September 28. URL: https://data.worldbank.org/indicator/SN.ITK.DEFC.ZS. 